\title{
ASSESSMENT OF DROUGHT IN AGRICULTURAL REGIONS OF SLOVAKIA USING SOIL WATER DYNAMICS SIMULATION
}

\author{
JOZEF TAKÁČ
}

Soil Science and Conservation Research Institute, Bratislava

TAKÁČ, J.: Assessment of drought in agricultural regions of Slovakia using soil water dynamics simulation. Agriculture (Pol'nohospodárstvo), vol. 59, 2013, no. 2, pp. 74-87.

Assessment of agronomic drought occurrence and severi-
ty in agricultural regions of Slovakia is presented in the
paper. Drought severity assessment is based on the soil
water dynamics simulation by agroecological model Dai-
sy. Daily meteorological data from the years 1961-2012
from 31 localities were used in simulations. Criteria for
the drought occurrence were 1) available soil water con-
tent below 50\% of available water capacity, 2) soil water
content below long-term average soil water content and
3) duration of continuous drought for fifteen or more days.
Standardized index of daily available soil water content

Key words: drought, precipitation, evapotranspiration, soil water content, available soil water, Daisy model

Drought is one of the major natural events with large environmental and socio-economic impacts. With regard to the problem complexity and its several aspects general definition of drought and general method for its quantification does not exist. Drought in general influences water shortage in the soil, plants or in the atmosphere. There can be distinguished meteorological drought, agronomic drought, hydrological drought and physiological drought (Sobíšek et al. 1993). Agronomic drought is defined as soil water shortage in consequence of previous or prevailing meteorological drought. Its effect is gradually cumulated with extending the duration of the drought period. Start, duration and drought severity is strengthened with increasing air temperature.

Increased occurrence of extreme precipitation totals was observed on one hand and on the other was used for drought severity classification. According to the index the drought is categorized into four degrees of severity from mild to extreme drought. Cumulative sum of available soil water index was used to drought quantification throughout its duration. Normal climate period $1961-$ 1990 was chosen as reference period to enable historical comparison of drought severity as well as climate change impacts. Extreme drought of the largest spatial extent was identified in 1990. Extreme drought occurred regionally in the southwest Slovakia in 1978 and in the southeast Slovakia in 1986 , respectively. hand, local or regional drought occurred more often in recent decades. According to the Fifth National Communication of the Slovak Republic on Climate Change (2009) extreme drought occurred in the years 1990 to 1994, 2000, 2002, 2003 and 2007. This fact was observed although average annual precipitation totals increased in two last decades in comparison to the normal period 1961-1990. Distribution as well as intensity of the precipitation was changed. Causality of increased drought occurrence is in increased evapotranspiration demand due to rising air temperature.

Drought impacts on land vulnerability will rise due to increasing commercial water requirements as well as climate change. Increasing number of unfavourable years for agricultural production from drought and heat waves in Europe with its economic consequences is assumed (EEA 2012). 
Drought is evaluated using various climatic indices usually calculated from empirical formulas. Climatic indices refer actual weather to the normal conditions and specify degree of drought abnormality. The most used climatic indices are $\%$ of normal, climate water balance, Humidity index according to Konček, Humidity index according to Thornthwaite, Lang's rain factor, Seljanin's hydrothermic coefficient (Sobíšek et al. 1993), Vysocki index, Budyko dryness index (Majerčák 2005), Aridity index (UNEP 1997), Standardised precipitation index SPI (McKee et al. 1993), Palmer drought severity index (Palmer 1965) and Crop moisture index CMI (Palmer 1968). Most of these indices are based only on precipitation. PDSI and CMI include simplified water balance. Choice and practical application of indices depends on user's demands.

Weakness of majority drought evaluating climatic indices is in no quantification the real water deficit due to different soil retention properties and that they do not reflect crop sensitivity to the water shortage. Time step used in the calculation can create disturbances too. Climatic indices which use annual or monthly data do not allow determine exactly the start and duration of drought.

For delimitation of drought periods is important to set the criteria. It is not sufficient to rely only on meteorological criteria when quantifying the drought in the soil. If criteria for the agronomic drought have been used it is possible to evaluate whether crop water requirements are fulfilled by the soil water storage at a given time (Tall \& Kandra 2007).

Crop growth is limited by sufficient amount of the water for evapotranspiration. Thus as the most suitable for drought assessment become the methods based on the soil moisture calculation. Soil water content is one of the most dynamic soil properties. Soil water dynamics and consequently soil drought occurrence is response to the natural factors and their spatial and temporal variability, particularly weather, ground water level, topography, hydrogeological conditions, canopy, soil physical and hydrophysical characteristics. Spatial and temporal variability of the acting natural factors is reflected in the spatial and temporal variability of the soil water content which is cause why the soil moisture measurements are not realistic in appropriate extent as they are costly and time consuming. On the other hand, modelling allows obtain continual series of soil water content in the daily step.

The goal of the paper is to present methodology of drought quantification and classification providing identification of anomalies. Common procedures based on soil water balance are used. Analysis of drought occurrence in agricultural regions of Slovakia in the years 1961-2012 are presented.

\section{MATERIAL AND METHODS}

Soil moisture is the limiting factor of evapotranspration. When soil water content is sufficient actual evapotranspiration is equal to the potential evapotranspiration. When soil water content is lower than its critical value actual evapotranspiration is reduced proportionally. Soil water below wilting point is not available for plants. Available for plants is soil water in the interval between field capacity FC [mm] and wilting point WP [mm]. Amount of soil water available for the plants is called available water capacity AWC $[\mathrm{mm}]$ :

$A W C=F C-W P$

In agronomic practise soil water storage is usually expressed as available soil water content ASWC [mm]:

$A S W C=S W C-W P$

Or ASWC [\% of AWC]:

$A S W C=\frac{S W C-W P}{F C-W P} .100=\frac{S W C-W P}{A W C} .100(3$

Soil water content SWC as well as FC and WP are calculated as weighted averages of horizons.

Equation (3) is usually used in irrigation schedules and soil moisture of $50 \%$ of AWC is in general recommendation to start irrigation of the key crops. Agronomic classification of soil water dynamics is based on the equation (3) (Benetin \& Šoltész 1988).

To evaluate anomalies in time series standardised indices are suitable. Standardised indices express relative relation of variable deviation from the average to standard deviation of time series. In general, standardised indices are used to compare large data sets, e.g. SPI (McKee et al. 1993). Proposed 
$\begin{array}{lllllllllll}\mathrm{T} & \mathrm{a} & \mathrm{b} & 1 & \mathrm{e} & 1\end{array}$

Degrees of drought severity based on the available soil water index ASWI

\begin{tabular}{|l|c|c|c|c|c|}
\hline Drought degree & Extreme drought & Severe drought & $\begin{array}{c}\text { Moderate } \\
\text { drought }\end{array}$ & Mild drought & Wet \\
\hline Probability interval [\%] & $\leq 2$ & 2.1 to 10 & 10.1 to 25 & 25.1 to 50 & $\geq 50$ \\
\hline ASWI interval [-] & $\leq-1.8$ & -1.8 to -1.151 & -1.15 to -0.721 & -0.72 to 0 & $\geq 0$ \\
\hline
\end{tabular}

standardised available soil water index ASWI is calculated from available soil water content ASWC in daily steps according to the equation:

$A S W I=\frac{A S W C-A S W C_{A V E}}{A S W C_{S D}}$

Where $\mathrm{ASWC}_{\mathrm{AVE}}$ is long term average of ASWC and $\mathrm{ASWC}_{\mathrm{SD}}$ is standard deviation of ASWC. Similarly in case of climatic indices for $\mathrm{ASWC}_{\mathrm{AVE}}$ and AS$\mathrm{WC}_{\mathrm{SD}}$ calculation it is required 30 year duration of the time series. Normal climate period 1961-1990 was chosen as reference period to enable historical comparison of drought severity as well as climate change impacts.

Standardisation allows achieve index distribution close to the normal (Gaussian) distribution (Takáč 2012). In accordance with assessment established in climatology (Lapin et al. 1988) boundaries of 25 $\%$ exceeding probability for moderate drought, 10 $\%$ exceeding probability for severe drought and 2 $\%$ exceeding probability for extreme drought have been set (Figure 1). Standardisation of ASWC allows compare drought severity not only in different periods but also in different regions with various soil and climate conditions. Averages of ASWI from considered set of meteorological stations were -0.72 for moderate drought, -1.15 for severe drought and -1.81 for extreme drought, respectively. Medians of ASWI were $-0.72,-1.16$ and -1.80 for individual drought degrees, respectively (Takáč 2012).

Drought is related to the long term mean conditions and it is defined as long term occurrence of SWC below average value. Basic assumptions for drought are 1) the SWC is below $50 \%$ of AWC and 2) SWC is below long term average SWC at the same time. Drought duration was defined as consecutive days of negative ASWI. Exceeding probability intervals of ASWI were used for drought severity classification (Table 1). The beginning of a drought period of given degree is determined by the day when ASWI falls below threshold value and a drought continues until the threshold is exceeded again. In order to classify the drought in a particular degree the duration must be continuously at least 15 days. In the case that the relevant condition lasts more than 15 days, shorter wetter periods are not considered as the end of drought period when they lasted less than $10 \%$ of previous drought period. These days are included in the drought period. Cumulative sum of ASWI was used to the drought quantification throughout its duration.

Drought assessment is based on the soil water dynamics simulations by agroecological model Daisy. Daisy simulates the crop production and the portion of water, nitrogen and carbon cycles that are related to the agricultural soil systems (Abraham-

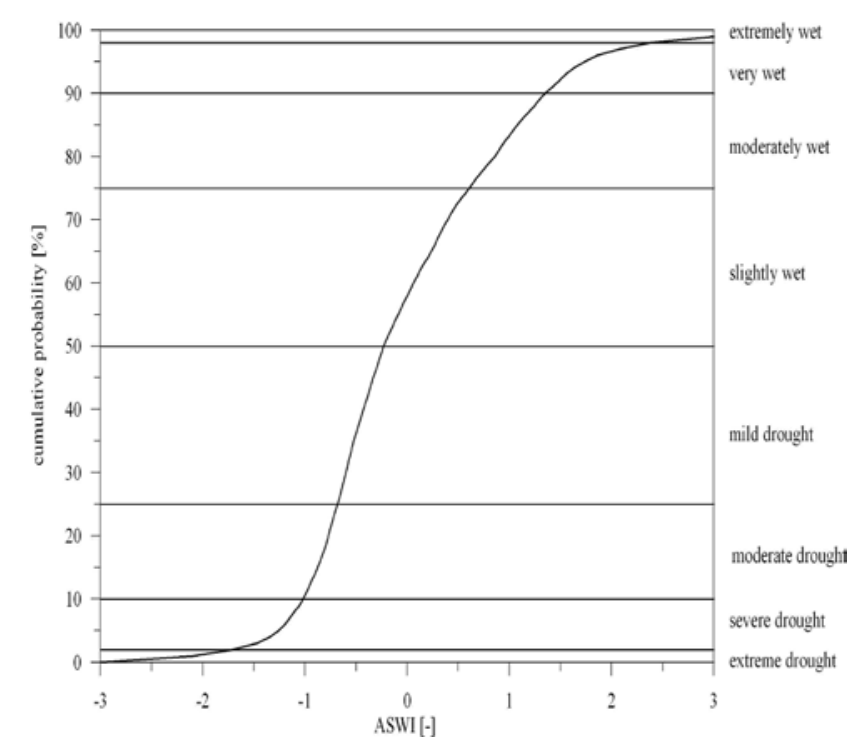

Figure 1. Cumulative probability of the ASWI in Hurbanovo in the period 1961-1990 and soil moisture classification based on the ASWI 


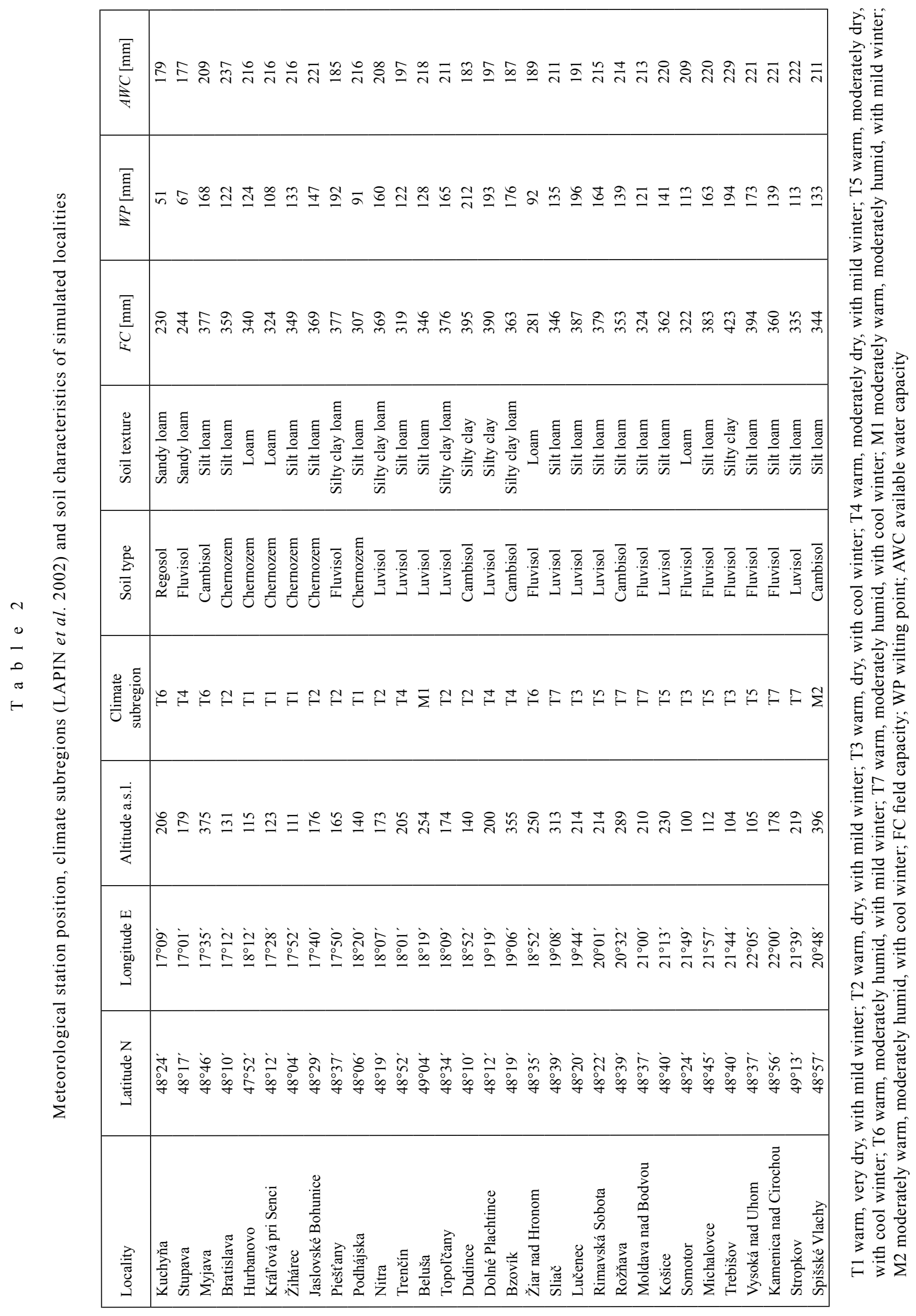


sen \& Hansen 2000; Hansen et al. 1990; Hansen 2000). The hydrological processes simulated by the model include snow accumulation and melting, interception, evaporation from the canopy, infiltration, ponding, surface runoff, water movement in soil matrix and macropores. Movement of the water within unsaturated zone is based on the numeric solution of the Richards equation (Richards 1931). Reliability of the model has been demonstrated in several comparative studies (Kröbel et al. 2010; Palusao et al. 2011; Rötter et al. 2012). Model crop parameters were optimised and verified for Slovak condition on the basis of experimental data (Takáč \& Šiška 2011).

$\mathrm{T}$ a

Mean annual simulated soil water content SWC [mm], available soil water content ASWC [mm] and available soil water content ASWC [\%] in the soil profiles 0-30 cm and $0100 \mathrm{~cm}$ in the period 1961-1990

\begin{tabular}{|c|c|c|c|c|c|c|}
\hline \multirow{2}{*}{ Locality } & \multicolumn{3}{|c|}{$0-30 \mathrm{~cm}$} & \multicolumn{3}{|c|}{$0-100 \mathrm{~cm}$} \\
\hline & $S W C[\mathrm{~mm}]$ & $A S W C[\mathrm{~mm}]$ & $A S W C[\%]$ & $S W C[\mathrm{~mm}]$ & $A S W C[\mathrm{~mm}]$ & $A S W C[\%]$ \\
\hline Kuchyňa & 51 & 34 & 59 & 152 & 101 & 57 \\
\hline Stupava & 52 & 36 & 64 & 186 & 119 & 67 \\
\hline Myjava & 88 & 59 & 79 & 353 & 185 & 89 \\
\hline Bratislava & 76 & 43 & 57 & 266 & 144 & 61 \\
\hline Hurbanovo & 70 & 37 & 57 & 246 & 122 & 57 \\
\hline Král'ová pri Senci & 65 & 37 & 53 & 227 & 119 & 55 \\
\hline Žihárec & 82 & 41 & 62 & 271 & 138 & 64 \\
\hline Podhájska & 63 & 33 & 53 & 207 & 115 & 53 \\
\hline Jaslovské Bohunice & 83 & 43 & 59 & 290 & 143 & 65 \\
\hline Piešt’any & 91 & 38 & 62 & 323 & 131 & 71 \\
\hline Nitra & 86 & 43 & 60 & 293 & 133 & 64 \\
\hline Trenčín & 76 & 42 & 58 & 273 & 151 & 77 \\
\hline Beluša & 89 & 59 & 87 & 335 & 207 & 95 \\
\hline Topol'čany & 76 & 37 & 53 & 292 & 126 & 60 \\
\hline Dudince & 97 & 43 & 68 & 364 & 152 & 83 \\
\hline Bzovík & 88 & 42 & 74 & 342 & 166 & 89 \\
\hline Žiar nad Hronom & 77 & 49 & 84 & 267 & 175 & 93 \\
\hline Sliač & 90 & 58 & 85 & 337 & 203 & 95 \\
\hline Dolné Plachtince & 96 & 43 & 64 & 350 & 158 & 80 \\
\hline Lučenec & 83 & 47 & 63 & 323 & 127 & 66 \\
\hline Rimavská Sobota & 82 & 54 & 68 & 338 & 174 & 81 \\
\hline Rožňava & 82 & 56 & 79 & 333 & 194 & 91 \\
\hline Moldava nad Bodvou & 81 & 56 & 81 & 313 & 192 & 90 \\
\hline Košice & 80 & 48 & 65 & 301 & 160 & 73 \\
\hline Somotor & 78 & 45 & 66 & 256 & 143 & 68 \\
\hline Michalovce & 89 & 53 & 73 & 321 & 158 & 72 \\
\hline Trebišov & 99 & 46 & 73 & 348 & 154 & 67 \\
\hline Vysoká nad Uhom & 93 & 50 & 72 & 357 & 184 & 83 \\
\hline Kamenica nad Cirochou & 95 & 61 & 84 & 346 & 207 & 94 \\
\hline Stropkov & 84 & 59 & 84 & 323 & 210 & 94 \\
\hline Spišské Vlachy & 86 & 51 & 78 & 323 & 190 & 90 \\
\hline
\end{tabular}


Daily data of mean, maximum and minimum air temperature, air humidity, global radiation, wind speed and precipitation for the period 1961 to 2012 from 31 meteorological stations used in simulations were provided by Slovak Hydrometeorological Institute. Simulations were carried out for five field crops (winter wheat, spring barley, maize, sugar beet and potato) and permanent grassland. Each crop was simulated every year in cropping patterns in six model runs.

Simulations were performed for representative soil profiles of considered regions (Table 2). Representative soil profiles were selected from the soil database of Complex soil survey of Slovakia (Nováková \& Skalský 2006; Skalský \& Balkovič 2002). Soil horizons were defined by texture, bulk density,

$\begin{array}{lllllllllllllll} & \mathrm{a} & \mathrm{b} & 1 & \mathrm{e} & 4\end{array}$

Sum of ASWI in five driest periods on the selected sites

\begin{tabular}{|c|c|c|c|c|c|c|c|c|c|c|}
\hline \multirow{2}{*}{ Locality } & \multicolumn{2}{|c|}{1} & \multicolumn{2}{|c|}{2} & \multicolumn{2}{|c|}{3} & \multicolumn{2}{|c|}{4} & \multicolumn{2}{|c|}{5} \\
\hline & year & $\Sigma$ ASWI & year & $\Sigma$ ASWI & year & $\Sigma$ ASWI & year & $\Sigma$ ASWI & year & $\Sigma$ ASWI \\
\hline Kuchyňa & 1990 & -695.6 & 1997 & -339.3 & 1974 & -264.8 & 2012 & -263.2 & 1978 & -257.7 \\
\hline Stupava & 1990 & -758.4 & 1974 & -248.2 & 1978 & -235.8 & 1983 & -232.9 & 2012 & -220.8 \\
\hline Myjava & 1991 & -177.0 & 2003 & -168.9 & 2000 & -168.3 & 1989 & -145.9 & 1992 & -138.1 \\
\hline Bratislava & 1990 & -585.7 & 1978 & -365.7 & 1998 & -338.2 & 1977 & -279.3 & 2003 & -278.2 \\
\hline Hurbanovo & 1978 & -603.1 & 1990 & -569.2 & 2012 & -285.0 & 1983 & -198.0 & 2003 & -171.8 \\
\hline Král'ová pri Senci & 1990 & -766.0 & 1978 & -588.1 & 2012 & -230.6 & 1983 & -228.0 & 1991 & -197.3 \\
\hline Žihárec & 1990 & -732.1 & 2012 & -339.7 & 1978 & -258.3 & 2011 & -219.7 & 1968 & -210.5 \\
\hline Jaslovské Bohunice & 1990 & -868.6 & 1978 & -293.2 & 1991 & -225.6 & 1997 & -217.5 & 1998 & -215.0 \\
\hline Piešt'any & 1989 & -353.0 & 1978 & -268.5 & 1983 & -224.4 & 1990 & -190.7 & 1971 & -178.3 \\
\hline Podhájska & 1990 & -539.0 & 1978 & -315.1 & 1971 & -295.3 & 1983 & -254.2 & 2012 & -183.1 \\
\hline Nitra & 1990 & -684.2 & 2012 & -273.7 & 1978 & -230.8 & 2006 & -218.1 & 1971 & -203.1 \\
\hline Trenčín & 1989 & -396.6 & 1997 & -344.0 & 1996 & -294.5 & 1990 & -238.5 & 1973 & 200.0 \\
\hline Beluša & 2003 & -315.9 & 2011 & -285.8 & 2012 & -282.6 & 2000 & -266.1 & 1983 & -221.4 \\
\hline Topol'čany & 1990 & -697.6 & 1971 & -290.2 & 1978 & -273.0 & 1983 & -268.4 & 2012 & -202.0 \\
\hline Dudince & 1990 & -202.2 & 1997 & -132.7 & 2000 & -130.9 & 1962 & -129.0 & 1983 & -126.6 \\
\hline Dolné Plachtince & 1986 & -191.9 & 2011 & -177.9 & 1990 & -167.1 & 2000 & -148.0 & 1983 & -142.5 \\
\hline Bzovík & 1990 & -233.8 & 2000 & -183.0 & 1993 & -178.7 & 1982 & -125.1 & 2007 & -123.0 \\
\hline Žiar nad Hronom & 2000 & -265.8 & 1993 & -241.5 & 2012 & -227.4 & 2003 & -199.5 & 2009 & -195.7 \\
\hline Sliač & 2012 & -252.5 & 2000 & -251.0 & 1993 & -198.1 & 1983 & -185.7 & 1973 & -153.8 \\
\hline Lučenec & 2002 & -564.7 & 1989 & -403.0 & 1988 & -283.0 & 2012 & -268.1 & 1983 & -230.8 \\
\hline Rimavská Sobota & 2012 & -248.2 & 1963 & -203.3 & 2000 & -200.8 & 1986 & -194.5 & 1993 & -193.7 \\
\hline Rožňava & 1986 & -260.0 & 1982 & -232.5 & 2012 & -213.5 & 2003 & -213.1 & 1993 & -212.3 \\
\hline Moldava nad Bodvou & 1986 & -358.2 & 2011 & -295.4 & 1993 & -280.8 & 1964 & -217.6 & 1968 & -211.3 \\
\hline Košice & 1973 & -361.0 & 2002 & -365.2 & 1986 & -342.2 & 2012 & -292.1 & 1993 & -234.4 \\
\hline Somotor & 1990 & -301.4 & 1986 & -295.4 & 2002 & -245.5 & 1962 & -234.9 & 1964 & -234.4 \\
\hline Michalovce & 1986 & -420.9 & 1963 & -292.5 & 1961 & -283.6 & 2011 & -231.8 & 1987 & -215.0 \\
\hline Trebišov & 1986 & -359.4 & 1999 & -184.1 & 1973 & -165.4 & 1993 & -153.0 & 2009 & -152.0 \\
\hline Vysoká nad Uhom & 1986 & -374.2 & 2011 & -234.9 & 1961 & -231.9 & 1962 & -188.3 & 2009 & -163.4 \\
\hline Kamenica nad Cirochou & 1961 & -360.8 & 2003 & -215.5 & 1962 & -195.1 & 1964 & -124.0 & 2007 & -122.5 \\
\hline Stropkov & 1961 & -351.9 & 2003 & -221.1 & 1962 & -178.1 & 1964 & -175.8 & 2011 & -157.0 \\
\hline Spišské Vlachy & 1961 & -412.8 & 1962 & -277.8 & 1964 & -160.3 & 1993 & -156.1 & 1967 & -141.9 \\
\hline
\end{tabular}


retention curve parameters, saturated hydraulic conductivity, humus content and $\mathrm{C} / \mathrm{N}$ ratio.

\section{RESULTS AND DISCUSSION}

Crop yields crucially depend on weather. Yield variability is significantly affected by soil water dynamics in growing period as well as outside of growing period. Consequence is given to the winter water supply. It is optimal if sufficient snow cover was formed during the winter and snow melts slowly in early spring. Distribution of the precipitation during the growing season plays important role too.

Soil water content shows natural annual cycle. Maximum soil water storage is at the end of the winter and minimum occurs in the summer months. For impacts of drought on crop growth, the drought duration, intensity and time of occurrence in terms of the crop development stage is crucial. In the case of extreme drought the impacts on yields may be severe.

Wet period with SWC above $50 \%$ of AWC dominates during the winter months. Drought of different intensity with SWC below $50 \%$ of AWC occurs almost every year in the summer months. Drought starts usually at first in southwest Slovakia later in central and eastern Slovakia. SWC falls below $50 \%$ of AWC in the western lowlands on average during June and in the south of central and eastern Slovakia in July (Figure 2). Drought severity and duration are different in each year. This can occur in early spring in some years or drought may persist from autumn and winter due to the lack of precipitation. In some years, the persistent winter drought continues over the next year. If soil water storage has not been refilled during the winter months the impacts of low summer precipitation are strengthened and almost complete drying of soil profile occurs.

Soil moisture is spatially heterogeneous. Soil water storage depends not only on refilling from precipitation and ground water table but it also depends on soil retention properties. The soil can retain different amounts of water in dependence on soil texture. The same quantity of water may represent sufficiency in one soil but deficiency in the other. Sandy soils have very little available water capacity. Loamy soils have the highest available water capacity. The time necessary for the formation of soil water deficit is different in dependence on soil retention capacity and thus the time when meteorological drought proceeds to the agronomic drought is different in dependence on soil retention capacity.

Effect of soil properties on available quantity of water for crops is obvious from the comparison of different way of expressing average SWC (Table 3). Although average precipitation totals in Kuchyňa are higher than in Hurbanovo average ASWC on loamy chernozem in Hurbanovo is higher than average ASWC on sandy loam regosol in Kuchyña. The same amount of SWC in Spišské Vlachy and Stropkov signifies different ASWC. The same amount of ASWC [mm] in Stupava and Král'ová pri Senci signifies different ASWC expressed in percentage. Different texture of soil horizons in Kuchyňa and
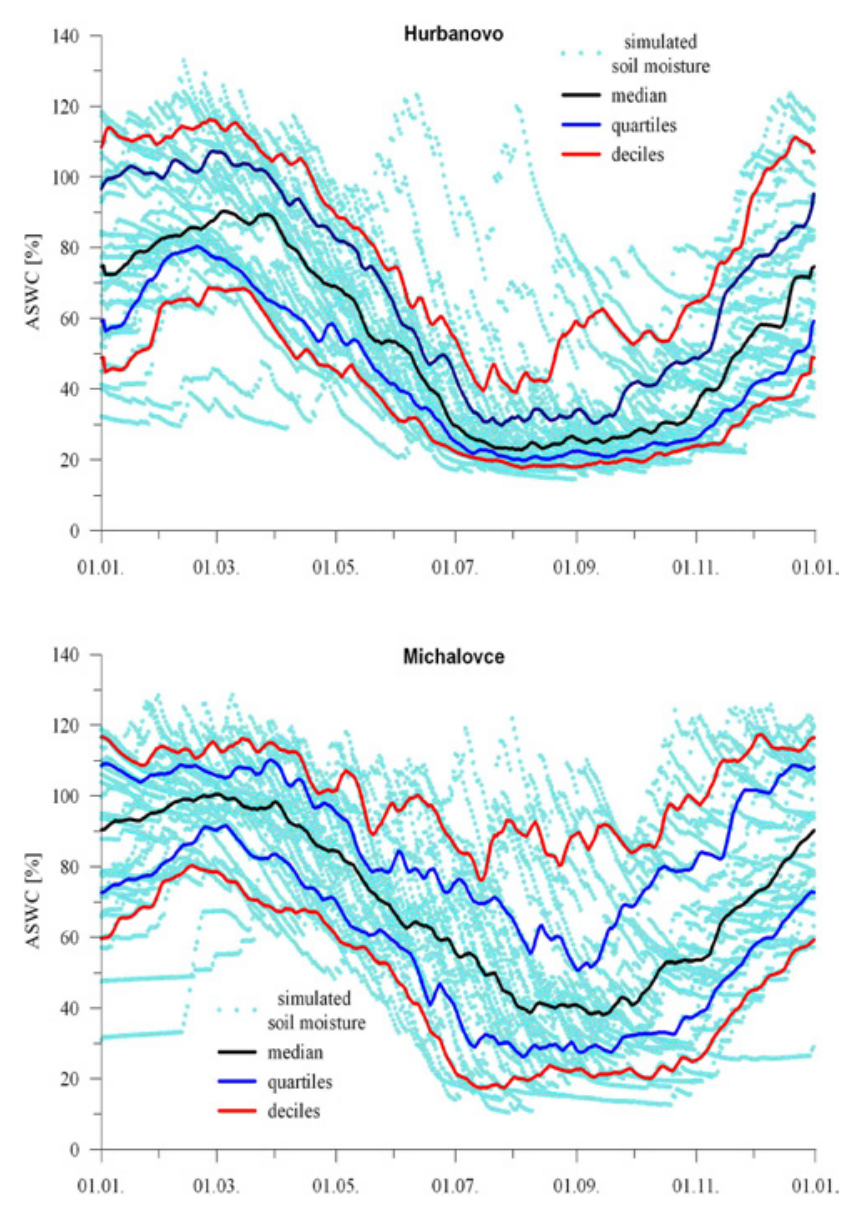

Figure 2. Annual cycle of soil water content [\% of AWC] in the soil horizon $0-100 \mathrm{~cm}$ in the period 1961-1990 in Hurbanovo and Michalovce 
Trebišov is reflected in lower ASWC [\%] of entire soil profile compared to the topsoil. There exist horizons below topsoil with lower AWC compared to AWC of the topsoil in these localities.

The highest average annual SWC was calculated throughout Slovakia in the years 1965 and 2010 (Figure 3). The lowest average annual SWC was simulated on the majority of localities in the year 1990. Average annual SWC was extremely low in the southwest also in the year 1978. Cause of the extremely low SWC in the years 1978 and 1990 is not only low precipitation in the summer months but also insufficient precipitation in the preceding winter period when soil water storage was not filled up as it was usual in the other years. Similar situation was also in the year 2012 when precipitation below average was recorded from the summer of the year 2011 to the autumn of the year 2012 .

Occurrence and duration of the period with SWC below $50 \%$ of AWC is different in the individual regions. Such period occurs in the west Slovakian lowlands almost every year. Median of continuous period with SWC below $50 \%$ of AWC is more than 50 days on the majority of evaluated sites. Median of continuous dry period is 166 days in Kuchyňa, 168 days in Hurbanovo and 169 days in Podhájska and Král'ová pri Senci (Figure 4). On these sites is one of four years SWC below 50\% of AWC more than 200 days. Average number of days with SWC below $50 \%$ of AWC from 31 sites
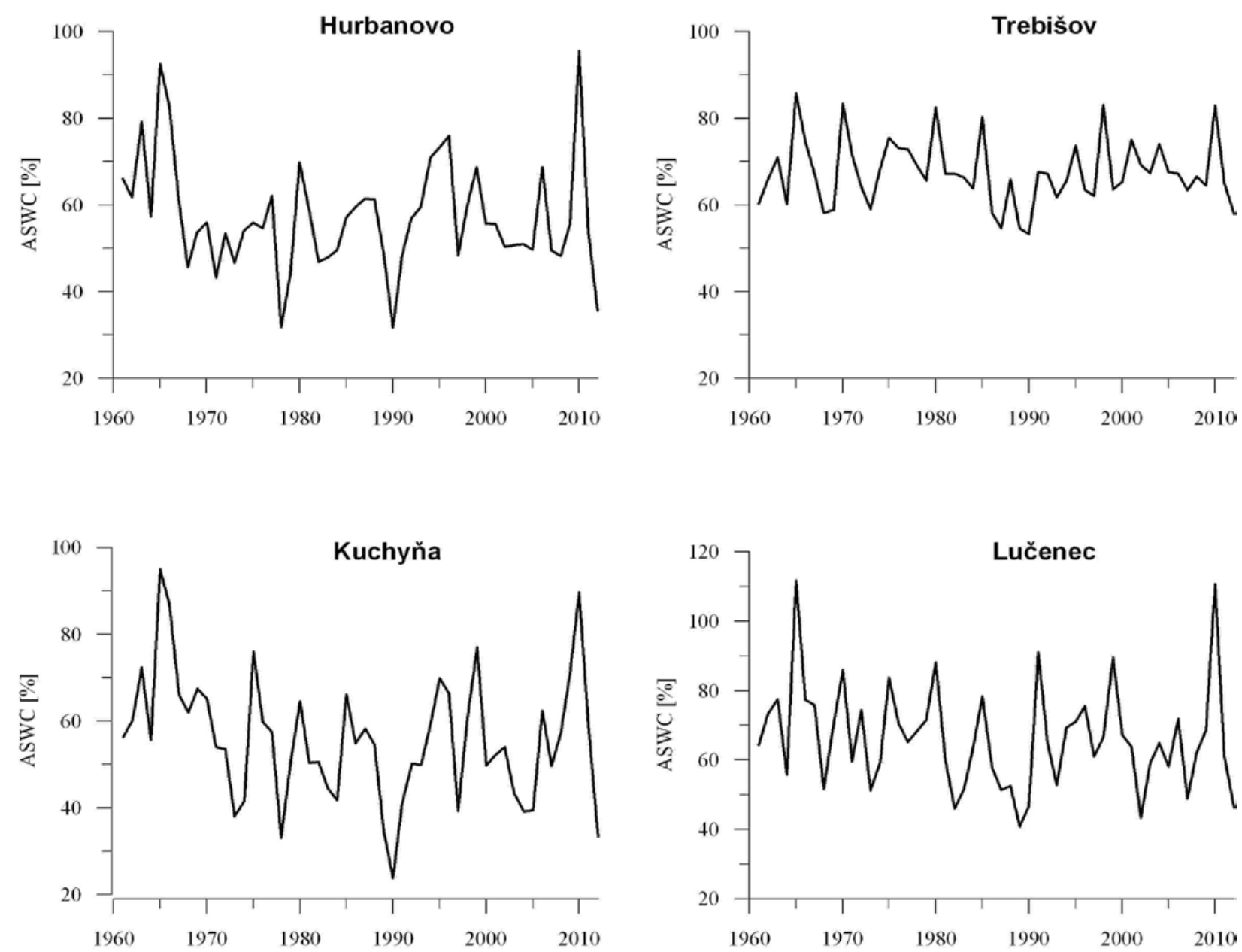

Figure 3. Mean annual soil water content SWC [\% of AWC] in selected sites in the period 1961-2012 
was 90 days in the period 1961-1990 and 96 days in the period 1991-2012.

Alternating wet and dry periods differs from the annual cycle according to the average monthly ASWI. Relatively dry and wet periods often last for more than one year (Figure 5). The longest recorded period of below-average soil moisture at most sites was around 2 years. The longest period was recorded in the Záhorská lowland and lasted from October 1988 to December 1991, i.e. 39 months.

According to the sum of ASWI the year 1990 was identified as the driest year on 12 from 31 sites mainly in the western Slovakia (Table 4). The driest year in southeast Slovakia was the year 1986 and in the northeast Slovakia the year 1961. The second driest year in the western Slovakia was the year 1978. The year 1983 was found mostly as the fourth or fifth driest year in western and central Slovakia. The year 2012 was in the majority of cases the third driest year but the driest year in Rimavská
Sobota and Sliač. Severe drought that occurred in other years had only local importance. These results correspond with the order of years according to the average annual SWC (see above).

Continuous drought persisted more than 400 days in period 1989-1990, the longest in Král'ová pri Senci -593 days (Table 5). The lowest $\Sigma$ ASWI was calculated in Jaslovské Bohunice (-868.6). Extreme drought in western Slovakia in the year 1990 was preceded by moderate to severe drought in the year 1989. Drought of 1989 continued steadily until 1990 in Záhorská lowland and in the southwest of Danubian Lowland while elsewhere it was interrupted for varying lengths of time. In some sites the drought in the previous year 1989 was more severe than the drought in the year 1990 (Myjava, Piešt'any and Lučenec). For instance in Lučenec severe drought occurred already in the year 1988. Severe and extreme drought continued also in the year 1989 till April 1990. Moderate

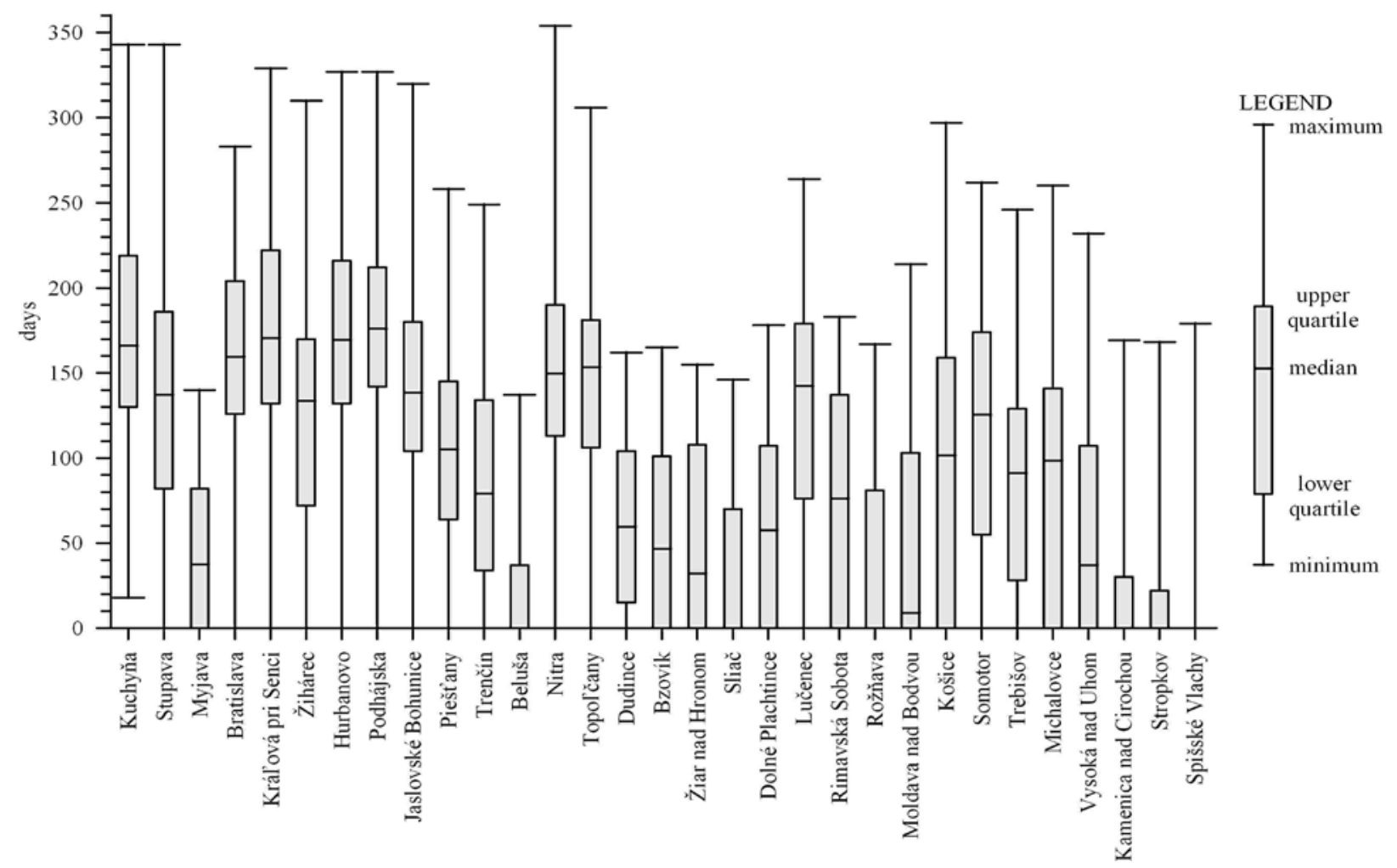

Figure 4. Statistical characteristics of the annual number of days with SWC below 50\% of AWC in the period 1961-2012 
drought followed from the end of June to the end of October 1990 (Figure 6).

In western Slovakia was extremely dry also the year 1978 that was preceded by moderate and severe drought in the year 1977. Severe and extreme drought continued in the southern part of Danubian Lowland also in the year 1979. Continuous drought persisted more than 200 days in this region, in Hurbanovo and Král'ová pri Senci it was almost 600 days. The lowest $\Sigma$ ASWI was calculated in Hurbanovo (-603.1). Neither in the southern part of central Slovakia nor in the eastern Slovakia the drought was present in the year 1978. For instance there were only 47 days of mild and moderate drought in Lučenec and 39 days of mild drought in Michalovce in the year 1978. In this part of Slovakia were the years 1977 and 1979 drier than the year 1978.
Continuous drought in East Slovakian Lowland lasted more than 200 days only in the year 1986 . The lowest $\Sigma$ ASWI was calculated in Michalovce $(-420.9)$.

Median of $\Sigma$ ASWI and lower quartile from 31 sites in the reference period 1961-1990 were -49 and -105 , respectively. Median of $\Sigma$ ASWI and lower quartile decreased in the period 1991-2012 to -75 and -133 , respectively. According to the average of $\Sigma$ ASWI from 31 sites equal to -240 the year 1990 was the driest one. The $\Sigma$ ASWI in the year 1990 was less than -100 in 21 sites, of which less than -200 in 14 sites and less than -300 in 10 sites.

From the assessment of the drought occurrence and duration according to $\Sigma$ ASWI it is evident that in the last decades the extreme drought occurs also in the regions in which drought has occurred in the

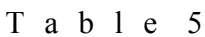

Drought characteristics in the year 1990

\begin{tabular}{|c|c|c|c|c|c|c|c|c|}
\hline \multirow{2}{*}{ Locality } & \multirow{2}{*}{ Rank } & \multirow{2}{*}{ Start date } & \multirow{2}{*}{ End date } & \multicolumn{2}{|c|}{ Continuous drought } & \multicolumn{3}{|c|}{ Of which [days] } \\
\hline & & & & [days] & $\Sigma$ ASWI [-] & $\begin{array}{l}\text { Moderate } \\
\text { drought }\end{array}$ & $\begin{array}{l}\text { Severe } \\
\text { drought }\end{array}$ & $\begin{array}{l}\text { Extreme } \\
\text { drought }\end{array}$ \\
\hline Kuchyňa & 1 & 10.5 .1989 & 9.12 .1990 & 579 & -695.6 & 404 & 239 & 139 \\
\hline Stupava & 1 & 24.5.1989 & 9.12 .1990 & 565 & -758.4 & 442 & 220 & 151 \\
\hline Bratislava & 1 & 13.9.1989 & 17.11.1990 & 431 & -585.7 & 376 & 225 & 147 \\
\hline Hurbanovo & 2 & 17.9.1989 & 28.10 .1990 & 433 & -569.2 & 345 & 205 & 155 \\
\hline Král'ová pri Senci & 1 & 12.4.1989 & 25.11 .1990 & 593 & -766.0 & 489 & 297 & 157 \\
\hline Žihárec & 1 & 15.6.1989 & 18.11.1990 & 522 & -732.1 & 436 & 258 & 166 \\
\hline Podhájska & 1 & 23.9.1989 & 28.10 .1990 & 401 & -539.0 & 370 & 218 & 130 \\
\hline Nitra & 1 & 18.9.1989 & 17.11 .1990 & 426 & -684.2 & 380 & 260 & 156 \\
\hline Jasl. Bohunice & 1 & 13.4.1989 & 16.11 .1990 & 583 & -868.6 & 503 & 350 & 197 \\
\hline Piešt'any & 4 & 19.5.1990 & 28.10 .1990 & 163 & -190.7 & 140 & 112 & 54 \\
\hline Trenčín & 4 & 21.5.1990 & 23.9.1990 & 126 & -238.5 & 109 & 57 & 35 \\
\hline Topol'čany & 1 & 12.5.1989 & 28.10 .1990 & 535 & -697.6 & 426 & 233 & 142 \\
\hline Dudince & 1 & 20.5.1990 & 28.10 .1990 & 162 & -202.2 & 162 & 107 & 0 \\
\hline D. Plachtince & 3 & 16.6.1990 & 28.10 .1990 & 135 & -167.1 & 135 & 41 & 0 \\
\hline Bzovík & 1 & 17.5.1990 & 28.10 .1990 & 165 & -233.8 & 165 & 107 & 22 \\
\hline Lučenec & 23 & 22.6 .1990 & 28.10 .1990 & 129 & -109.6 & 67 & 0 & 0 \\
\hline Rimavská Sobota & 27 & 21.7.1990 & 7.10 .1990 & 79 & -67.0 & 54 & 0 & 0 \\
\hline Michalovce & 30 & 16.7 .1990 & 6.10 .1990 & 83 & -50.3 & 35 & 0 & 0 \\
\hline Trebišov & 11 & 21.7.1990 & 28.10 .1990 & 100 & -82.6 & 71 & 0 & 0 \\
\hline Somotor & 1 & 23.3 .1990 & 2.11 .1990 & 225 & -301.4 & 220 & 103 & 53 \\
\hline
\end{tabular}


previous decades only rarely. Five driest periods occurred in Myjava from the year 1989 and in Žiar nad Hronom from the year 1993. Four driest periods occurred in Beluša from the year 2000 (Table 4). Regional extent of drought increased in the last two decades. While in the period 1961-1990 इASWI < -100 was on average annually at 9 sites, in the pe- riod 1991-2012 it was already on average annually at 12 sites. $\Sigma$ ASWI $<-100$ in 20 and more sites occurred in the years 1983, 1990, 2000, 2003, 2007, 2011 and 2012, thus mainly after 1990. Drought of $\Sigma$ ASWI $<-100$ had the largest spatial extension in the years 2003, 2000 and 2012 when occurred at 28, 27 and 28 sites, respectively thus again in the recent
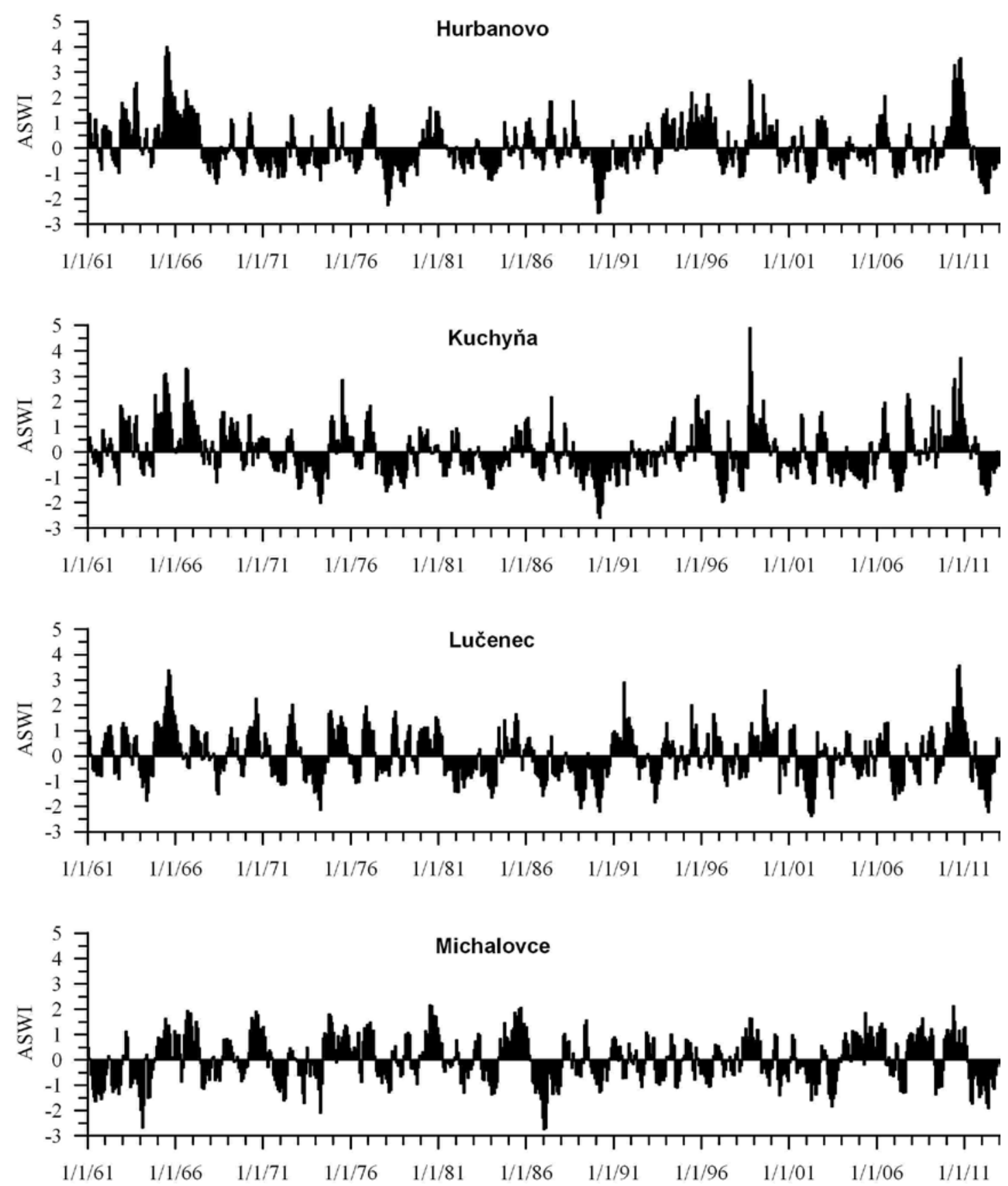

Figure 5. Duration of dry and wet periods according to mean monthly ASWI in selected sites in the period 19612012 
years. Drought of $\Sigma$ ASWI $<-100$ had the largest spatial extension in the year 2012 when this value was reached even at 16 sites.

As regards the climate indices the driest year according to the Aridity index was the year 2003 in western Slovakia and the year 1961 in eastern Slovakia. The driest years according to the percent of normal as well as SPI were the years 2003, 1971 and 1989 in western Slovakia and the year 1961 in eastern Slovakia. The years 2003, 2011 and 1986 were driest according to the climate water balance (Takáč et al.2012). According to $\Sigma$ ASWI of the above years the year 2003 was the driest one only in Beluša and second driest year in four sites. The years 1961 and 1986 were the driest years in 3 sites and in 6 sites in eastern Slovakia, respectively. The year 1989 was the driest years in 2 sites in the middle part of Váh river basin.

Tall and Gomboš (2011) carried out evaluation of the drought in Milhostov in East Slovakian Lowland using several climatic indices. The driest years were the years 1961, 1967 and 1993 according to Lang's rain factor and Seljanin's hydrothermic coefficient, the years 1967, 1961 and 1993 according to Vysocki index, the years 1967, 1961 and 2003 according to the climate water balance, the years 2007, 1986 and 1996 according to the evapotranspiration deficit and the years 2007, 1968 and 1969 according to the PDSI. As shown usage of various indices gives different results. From all these years only the year 1986 was calculated among three driest years in this site according to $\Sigma$ ASWI.

When climatic indices are used entire precipitation totals are included in calculation. There is not considered surface runoff in the case of inefficient heavy rainfall. Models simulate surface runoff and in addition they include water losses due to interception, evaporation from the canopy, ponding, percolation from macropores and soil matrix. These processes play an important role in the soil water balance. Therefore simulation results give more precise information on water availability for crops and drought occurrence.

\section{CONCLUSION}

Prolonged continuous dry periods occur regularly in the lowlands. Duration of the continuous dry periods is shorter in the foothill areas and basins. Generally occurrence and duration of dry peri-

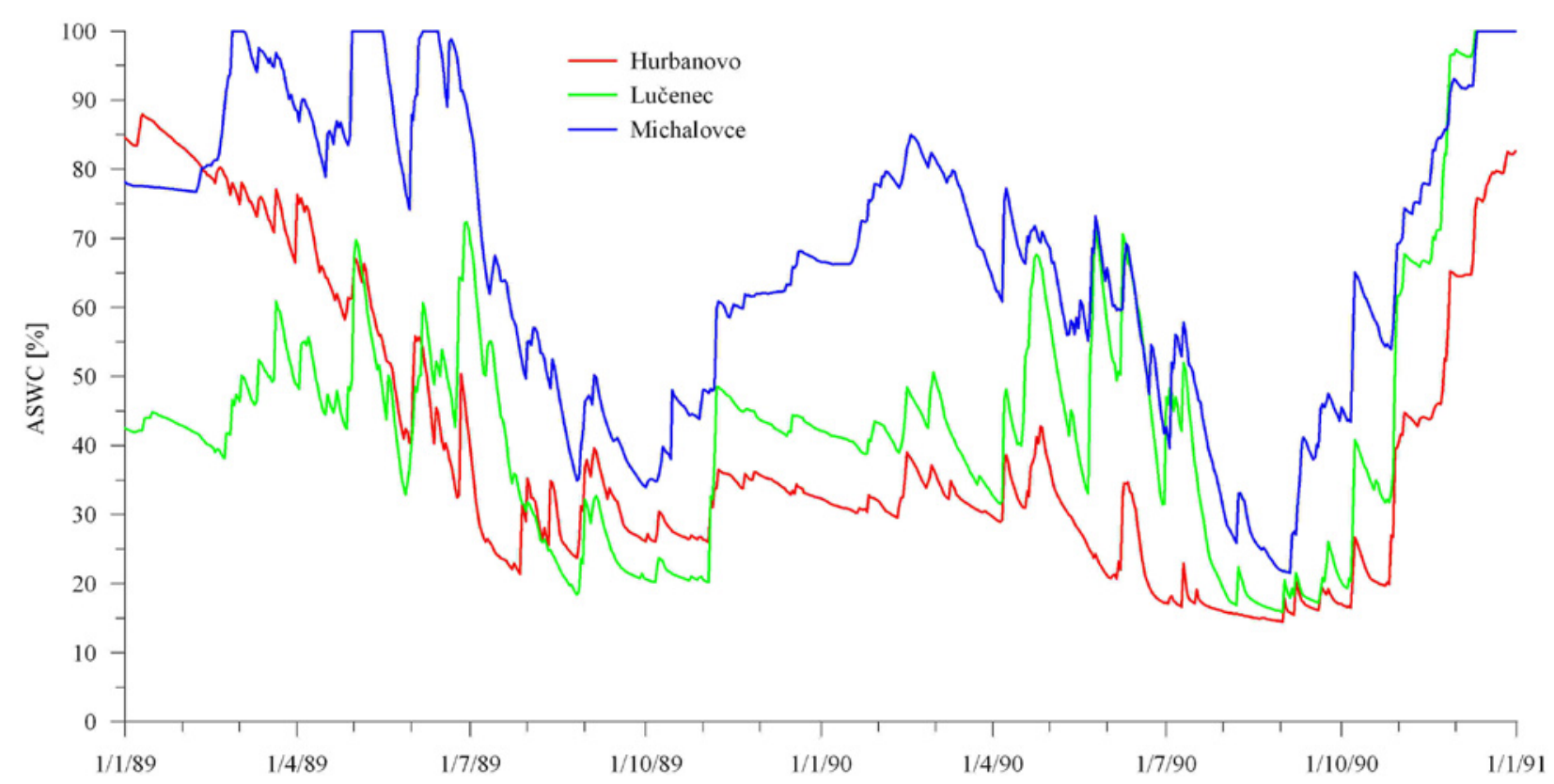

Figure 6. Daily soil water content SWC [\% of AWC] in selected sites in the period 1989-1990 
ods decreases from south to north and from west to east. This zoning is partially interrupted due to the different soil retention capacity in evaluated sites. Alternating wet and dry periods differs from the annual cycle. Drought severity strengthens when the drought occurred also in the previous year.

The procedure used allows classify the longterm drought throughout the duration of its effects. It is applicable to assess the current situation in real time. The introduction of the reference period allows expression of the drought severity in historical context. Linking climate database, soil database and GIS enables use this procedure to build an information system of drought. For the assessment of the long term trends is necessary to use the longest time series.

Acknowledgement. This study was carried out under the contract "Defining less favourable areas (LFA) for Agriculture in the Slovak Republic" according to the criteria proposed by European Commission's for other LFA and determination the terms and payments for all categories of LFA for the 20142020 programme period. Project was supported by Ministry of Agriculture and Rural Development of the Slovak Republic.

\section{REFERENCES}

ABRAHAMSEN, P. - HANSEN, S. 2000. Daisy: An open soil - plant - atmosphere system model. In Environmental Modelling \& Software, vol. 15, pp. 313-330.

BENETIN, J. - ŠOLTÉSZ, A. 1988. Hydrologické charakteristiky vodného režimu pôd a ich výpočet [Soil water regime characteristics and their calculation]. In Agromelio. Nitra : ČSVTS. pp.12-20.

EUROPEAN ENVIRONMENTAL AGENCY. 2012. Climate change, impacts and vulnerability in Europe 2012. An Indicator Based Report. EEA Report No. 12/2012. 300 p. ISBN 978-92-9213-346-7

HANSEN, S. - JENSEN, H.E. - NIELSEN, N.E. SVENDSEN, H. 1990. DAISY - a soil plant system model. Danish simulation model for transformation and transport of energy and matter in the soil-plantatmosphere system. Copenhagen : National Agency for Environmental Protection, 272 p. ISBN 87-5038790-1.

HANSEN, S. 2000. DAISY, a flexible soil - plant - atmosphere system model. Equation section 1. Copenhagen : The Royal Veterinary and Agricultural University. $47 \mathrm{p}$.
KRÖBEL, R. - SUN, Q. - INGWERSEN, J. - CHEN, X. - ZHANG, F. - MÜLLER, T. - RÖMHELD, V. 2010. Modelling water dynamics with DNDC and DAISY in a soil of the North China Plain: A comparative study. In Environmental Modelling \& Software, vol. 25, pp. 583-601. DOI: 10.1016/j.envsoft.2009.09.003.

LAPIN, M. - FAŠKKO, P. - KVETÁK, Š. 1988. Metodický predpis 3-09-1/1. Klimatické normály [Methodological prescription 3-09-1/1. Climate normals]. Bratislava: SHMÚ. $25 \mathrm{p}$.

LAPIN, M. - FAŠKO, P. - MELO, M. - ŠŤASTNÝ, P. - TOMLAIN, J. 2002. Klimatické oblasti [Climatic regions]. In HRNČIAROVÁ, T. (Ed.) Atlas krajiny Slovenskej republiky [Landscape Atlas of the Slovak Republic]. MŽP SR, Bratislava, AŽP SR, Banská Bystrica. 344 pp. ISBN 80-88833-27-2.

MAJERČÁK, J. 2005. Matematický model a indexy sucha [Mathematical model and drought indices]. In SOBOCKÁ, J. (Ed.): Štvrté pôdoznalecké dni na Slovensku (Zbornik referátov z vedeckej konferencie pôdoznalcov SR), Bratislava : Výskumný ústav pôdoznalectva a ochrany pôdy. pp. 207 - 213, ISBN 80-89128-18-1.

McKEE, T.B. - DOESKEN, N.J. - KLEIST, J. 1993. The relationship of drought frequency and duration to time scales. In Proceedings of the 8 th Conference on Applied Climatology, January 17-22, American Meteorological Society, Anaheim CA, USA. pp. 179184.

MINISTRY OF THE ENVIRONMENT OF THE SLOVAK REPUBLIC AND THE SLOVAK HYDROMETEOROLOGICAL INSTITUTE. 2009. The fifth national communication of the Slovak Republic on climate change under UNFCCC and Kyoto Protocol. Bratislava. $158 \mathrm{p}$.

NOVÁKOVÁ, M. - SKALSKÝ, R. 2006. Soil data potential for its application in process of selected crops yield prediction. In Agriculture (Pol'nohospodárstvo), vol. 52, no. 4, pp. 177-188.

PALMER, W.C. 1965. Meteorological Drought. Research Paper No. 45. U.S. Weather Bureau, Washington, D.C.

PALMER, W.C. 1968. Keeping track of crop moisture conditions, nationwide: The new crop moisture index. In Weatherwise, vol. 21 , no. 4, pp. 156-161.

PALOSUO, T. - KERSEBAUM, K.CH. - ANGULO, C. - HLAVINKA, P. - MORIONDO, M. - OLESEN, J.E. - PATIL, R.H. - RUGET, F. - RUMBAUR, CH. - TAKÁČ , J. - TRNKA, M. - BINDI, M. - CALDAG, B. EWERT, F. - FERRISE, R. - MIRSCHEL, W. - SAYLAN, L. - ŠIŠKA, B. - RÖTTER, R. 2011. Simulation of winter wheat yield and its variability in different climates of Europe: A comparison of eight crop growth models. In European journal of agronomy, vol. 35, no. 3, pp. 103-114. DOI: 10.1016/j.eja.2011.05.001.

RICHARDS, L.A. 1931. Capillary conduction of liquids through porous media. In Physics, vol. 1, no. 5 , pp. 318-333.

RÖTTER, R. - PALOSUO, T. - KERSEBAUM, K.CH. - ANGULO, C. - BINDI, M. - EWERT, F. - FERRISE, R. - HLAVINKA, P. - MORIONDO, M. - NEN- 
DEL, C. - OLESEN, J.E. - PATIL, R.H. - RUGET, F. - TAKÁČ, J. - TRNKA, M. 2012. Simulation of spring barley yield in different climatic zones of Northern and Central Europe: A comparison of nine crop models. In Field Crops Research, vol. 13, pp. 23-36. ISSN 0378-4290.

SKALSKÝ, R. - BALKOVIČ, J. 2002. Digital database of selected soil profiles of complex soil survey of Slovakia (KPP-DB). In Vedecké práce Výskumného ústavu pôdoznalectva a ochrany pôdy, 25, Bratislava : VÚPOP, pp. 129-140, ISBN 80-89128-07-6.

SOBÍŠEK, B. et al. 1993. Meteorologický slovník výkladový a terminologický [Meteorological explanatory and terminological dictionary]. ACADEMIA, MŽP ČR : Praha. 594 p. ISBN 80-85368-45-5.

TAKÁČ, J. - S̆IŠKA, B. - NOVÁKOVÁ M. 2012. Porovnanie výskytu sucha na Slovensku podla rôznych klimatických indikátorov [Comparison of drought occurrence in Slovakia according to the various climatic indicators]. In Zbornik z vedeckého seminára Environmentálne indexy a indikátory ako nástroje analýzy a hodnotenia stavov a procesov v krajine. Bratislava : VÚPOP, pp. 151-164. ISBN 978-80-89128-97-6.

TAKÁČ, J. - ŠIŠKA, B. 2011. Kalibrácia a validácia modelu DAISY pre podmienky Slovenska [Calibration and validation of DAISY model in conditions of the Slovak Republic]. In Vedecké práce Výskumného ústavu pôdoznalectva a ochrany pôdy, 33, Bratislava : VÚPOP, pp. 161-172. ISBN 978-80-89128-91-4.

TAKÁČ, J. 2012. Hodnotenie závažnosti sucha založené na modelovaní vlhkosti pôdy [Drought severity assessment based on the soil moisture modelling]. In Vedecké práce Výskumného ústavu pôdoznalectva a ochrany pôdy, 34, Bratislava : VÚPOP, pp. 153-168. ISBN 97880-89128-98-3.

TALL, A. - GOMBOŠ, M. 2011. Aplikácia Palmerovho indexu pre hodnotenie sucha [Application of Palmer drought severity index for evaluation of drought]. In SALAŠ, P. (Ed.): Rostliny v podmínkách ménicího se klimatu. Úroda, vědecká př́loha, pp. 623-628. ISSN 0139-6013.

TALL, A. - KANDRA, B. 2007. Zhodnotenie vodného režimu pôdy s ohl'adom na pôdne sucho [Evaluation of soil's water regime according to soil drought] In Acta Hydrologica Slovaca, vol. 8, no. 1, pp. 119-126.

UNEP, 1997. World Atlas of Desertification. 2. ed. 182 pp. ISBN 340691662.

Received: April, 22 $2^{\text {th }}, 2013$ 